\title{
Neurosurgical Treatment of Cerebrovascular Complications of Heart Surgeries and Interventions
}

\author{
Kalp Ameliyatları ve Girișimlerinin Serebrovasküler \\ Komplikasyonlarmm Nöroşirürjikal Tedavisi
}

\author{
Jan CHRASTINA ${ }^{1,2}, Z_{\text {deněk NOVÁK }}^{1,2}$, Jaroslav BRICHTA ${ }^{3}$, Petr PAVLÍK ${ }^{4}$, Ivo ŘíHA ${ }^{1,2}$, Petr NĚMEC ${ }^{4}$ \\ ${ }_{1}^{1}$ Masaryk University, School of Medicine, St. Anne's Teaching Hospital, Department of Neurosurgery, Pekarska 53, Brno, Czech Republic \\ ${ }^{2}$ CEITEC - Central European Institute of Technology, Masaryk University, Brno, Czech Republic \\ ${ }^{3}$ Masaryk University, School of Medicine, St. Anne's Teaching Hospital, First Department of Neurology, Pekarska 53, Brno, Czech Republic \\ ${ }^{4}$ Department of Cardiovascular and Transplantation Surgery, Pekarska 53, Brno, Czech Republic
}

Corresponding Author: Jan CHRASTINA / E-mail: jan.chrastina@fnusa.cz

\begin{abstract}
AIM: Intracerebral haematoma and brain ischaemia are rare life-threatening complications of cardiovascular surgery. The aim of this study is to present the experience with the neurosurgical treatment of patients with cerebrovascular complications of heart surgery.

MATERIAL and METHODS: Patients with brain ischaemia or intracerebral haematoma in the acute phase after heart surgery or invasive intervention operated on between 2002 and 2011 were reviewed. There were 3 patients with middle cerebral artery infarction requiring decompressive craniectomy ( 2 males, 1 female; mean age 54.3 years) and 5 patients with intracerebral haematoma ( 3 males, 2 females; mean age 55 years). The type of surgery for intracerebral haematoma was selected individually preferring minimally invasive techniques: stereotactic aspiration ( 2 patients), neuroendoscopy (1 patient), stereotactic craniotomy (1 patient) or classical craniotomy (1 patient).

RESULTS: The results of decompressive craniectomy were unsatisfactory: GOS 1, 3 and 4 in 1 patient each. The results of surgery for intracerebral haematoma were GOS 5 in 1 patient, GOS 4 in 2 patients, and lethal in 2 patients.

CONCLUSION: Minimally invasive neurosurgery techniques appear to be beneficial for selected patients with intracerebral haematoma after heart surgeries even when considering the limited number of patients. Decompressive craniectomy should be considered strictly individually. KEYWORDS: Brain ischaemia, Cardiovascular surgery, Decompressive craniectomy, Intracerebral haematoma, Stereotaxy
\end{abstract}

öz

AMAÇ: Intraserebral hematom ve beyin iskemisi kardiyovasküler cerrahinin hayatı tehdit eden nadir komplikasyonlarıdır. Bu çalışmanın amacı, kalp ameliyatı geçiren ve serebrovasküler komplikasyonları olan hastalarda nöroşirürjikal açıdan tedavi deneyimlerimizi sunmaktır.

YÖNTEM ve GEREÇLER: Kalp ameliyatı ya da invaziv müdahale sonrası akut fazda beyin iskemisi veya intraserebral hematom bulunan ve 2002 ve 2011 yılları arasında ameliyat olan hastalar gözden geçirildi. Dekompresif kraniyektomi gerektiren orta serebral arter enfarktüsü olan 3 hasta (2 erkek, 1 kadın; yaş ortalaması 54,3 yıl) ve intraserebral hematom olan 5 hasta (3 erkek, 2 kadın; yaş ortalaması 55 yıl) vardı. Intraserebral hematom için cerrahi yaklaşımda minimal invaziv teknikler tercih edildi ve bireysel olarak seçildi: stereotaktik aspirasyon ( 2 hasta), nöroendoskopi (1 hasta), stereotaktik kranyotomi (1 hasta) veya klasik kranyotomi (1 hasta).

BULGULAR: Dekompresif kraniyektominin sonuçları tatminkar değildi. Her bir hastada GOS 1, 3 ve 4 olarak izlendi. İntraserebral hematom için cerrahi tedavinin sonuçları; 1 hastada GOS 5, 2 hastada GOS 4, ve 2 hastada ise öldürücüydü.

SONUÇ: Hasta sayısının sınırlı olması dikkate alındığında bile minimal invaziv nöroşirürji teknikleri, kalp ameliyatları sonrası intraserebral hematom gelişen seçilmiş hastalarda yararlı gibi görünmektedir. Dekompresif kraniyektomi kesinlikle hastanın durumuna göre dikkate alınmalıdır.

ANAHTAR SÖZCÜKLER: Beyin iskemisi, Kardiyovasküler cerrahi, Dekompresif kraniyektomi, İntraserebral hematom, Stereotaksi

ABBREVIATIONS: GCS: Glasgow coma scale , GOS: Glasgow outcome scale , TIA: transient ischemic attack

\section{INTRODUCTION}

Although rare, brain ischemia and intracerebral haematoma are life-threatening complications of heart and large vessel surgery. The incidence of cerebrovascular complications of heart surgeries as reported in the literature varies. A retrospective study by Korn-Lubetzki et al. analysed 5275 patients after heart and major vessel surgeries. The authors found 78 ischemic strokes, more frequently after complex heart surgeries (1.47\%). Surprisingly, there was no case of intracerebral haematoma (18). The authors' conclusions 
about the absence of intracranial haemorrhage complicating heart surgery are not supported by other authors. Yuan and Guo analysed studies of intracranial haemorrhages after open-heart surgeries published between 1996 and 2000 (35 papers). Their review reports 179 patients with 182 intracranial haematomas (34).

From a general neurosurgical point of view, haematoma evacuation should be considered in patients with expansive intracerebral haematomas without irreversible brain tissue damage. Surgical decompression is needed in patients with expansive middle cerebral artery infarction or cerebellar ischaemia with brainstem compression.

In patients with intracerebral haematoma or expansive ischaemic lesion after heart and large vessel surgery, other factors that influence surgical decision-making should be considered, particularly anticoagulation or antiaggregation treatment, changes in the haemocoagulation system after extracorporeal circulation or hypothermia, circulatory instability, and immunosuppression after heart transplantation. All these factors, only rarely found in the general neurosurgery population, make the surgery and postoperative course more demanding and complicated.

The aim of this study is to present our experiences with the neurosurgical treatment of patients with cerebrovascular complications after heart surgeries or invasive cardiosurgical interventions, and to describe the surgical attitude to these exceptional and complicated patients and treatment outcomes.

\section{METHODS}

Patients with intracerebral haematoma or brain ischaemia (middle cerebral artery malignant infarction) in the acute phase ( $<14$ days) after heart surgery or invasive cardiosurgical intervention requiring neurosurgical treatment operated on between 2002 and 2011 were retrospectively identified from surgical reports. Radiological images and hospital and outpatient records were reviewed. The study included 8 patients (Tables I, II) from approximately 11000 heart and large vessels surgeries performed during the same time period. In another 12 patients with intracerebral haematoma or brain ischaemia in the acute phase ( $<14$ days) after heart surgery, no surgical treatment was indicated because of either grave clinical status or good patient condition with small haematoma or not expansive ischemic lesion.

The principles of anticoagulation and antiaggregation therapy as currently used in the Department of Cardiovascular and Transplantation Surgery after different types of heart surgeries are presented in Table III. In complicated patients (multiple organ failure, extracorporeal elimination, intermittent hemodialysis, prolonged artificial respiration, sepsis) a continuous infusion of unfractionated heparin 500020000 units/daily is administered until stabilization.

\section{Cerebral Ischaemia after Heart Surgery}

Decompressive craniectomy was performed in 3 patients
( 2 males, 1 female; ages $22-77$ years, mean age 54.3 years) with expansive stroke affecting the middle cerebral artery terrritory. Two patients with brain ischaemia had aortocoronary bypass surgery (in 1 patient with left internal carotid artery endarterectomy contralateral to the side of the stroke) and the remaining patient was re-operated for pulmonary artery stenosis and atrial septum defect. Of the 3 patients with ischaemic stroke, 2 deteriorated immediately after heart surgery and in 1 the time between heart surgery and neurological worsening was 24 hours. The time interval between the onset of neurological symptoms and craniectomy was 24,24 , and 48 hours. One patient with ischemic stroke was operated on while in a coma, and 2 patients were drowsy with focal deficit (GCS 9 and 10).

In all patients with middle cerebral artery ischaemic stroke, a large decompressive craniectomy on the side of the stroke with dural opening was performed. The final outcome was evaluated using Glasgow Outcome Scale (GOS) and Rankin scale.

\section{Intracranial Haematoma after Heart Surgery}

Five patients were operated on for intracerebral haematoma (3 males, 2 females; ages 38-73 years, mean age 55 years): 2 basal ganglionic, 1 temporoparietal, 1 parietooccipital, and 1 frontal haematoma with cerebellar abscess. Two patients with intracerebral haematoma underwent heart transplantation and 2 patients cardiac valve surgery, in one case this was an emergency surgery for infectious endocarditis affecting the mitral and aortic valves. In 1 patient, the cause of intracerebral haematoma was local thrombolysis for prosthetic mitral valve (10 months after surgery).

The onset of clinical symptoms of intracerebral haematoma was immediate after primary heart surgery in 2 patients; in the remaining 3 patients, the time between surgery and clinical symptoms was 4,10 , and 10 days. Two patients with brain haemorrhage had surgery while in a coma. In the other patients, presurgical Glasgow Coma Scale (GCS) score was 10, 10 , and 12 with severe limb paresis or speech disturbance. Two patients were operated on immediately after the diagnosis of intracerebral bleeding. The remaining 3 patients underwent surgery after necessary preparations: the same day, 24 hours, and 72 hours postoperatively. Haematoma volume $\mathrm{V}$ was calculated using the standard formula $V=(A \times B \times C) / 2$, where $A$ is anteroposterior, $B$ mediolateral, and $C$ superoinferior haematoma diameter.

Anticoagulation therapy with warfarin was administered at the time of haematoma occurrence (10 days after surgery) in 1 patient. Warfarin treatment was stopped prior to surgery, and surgical treatment was postponed until normalization of haematological parameters with substitution because of the patient's stable clinical status ( 72 hours after haematoma onset). A low molecular-weight heparin treatment was started in the evening after surgery.

In the patient with intracerebral bleeding after thrombolysis for artificial valve thrombosis, surgery was postponed for 24 


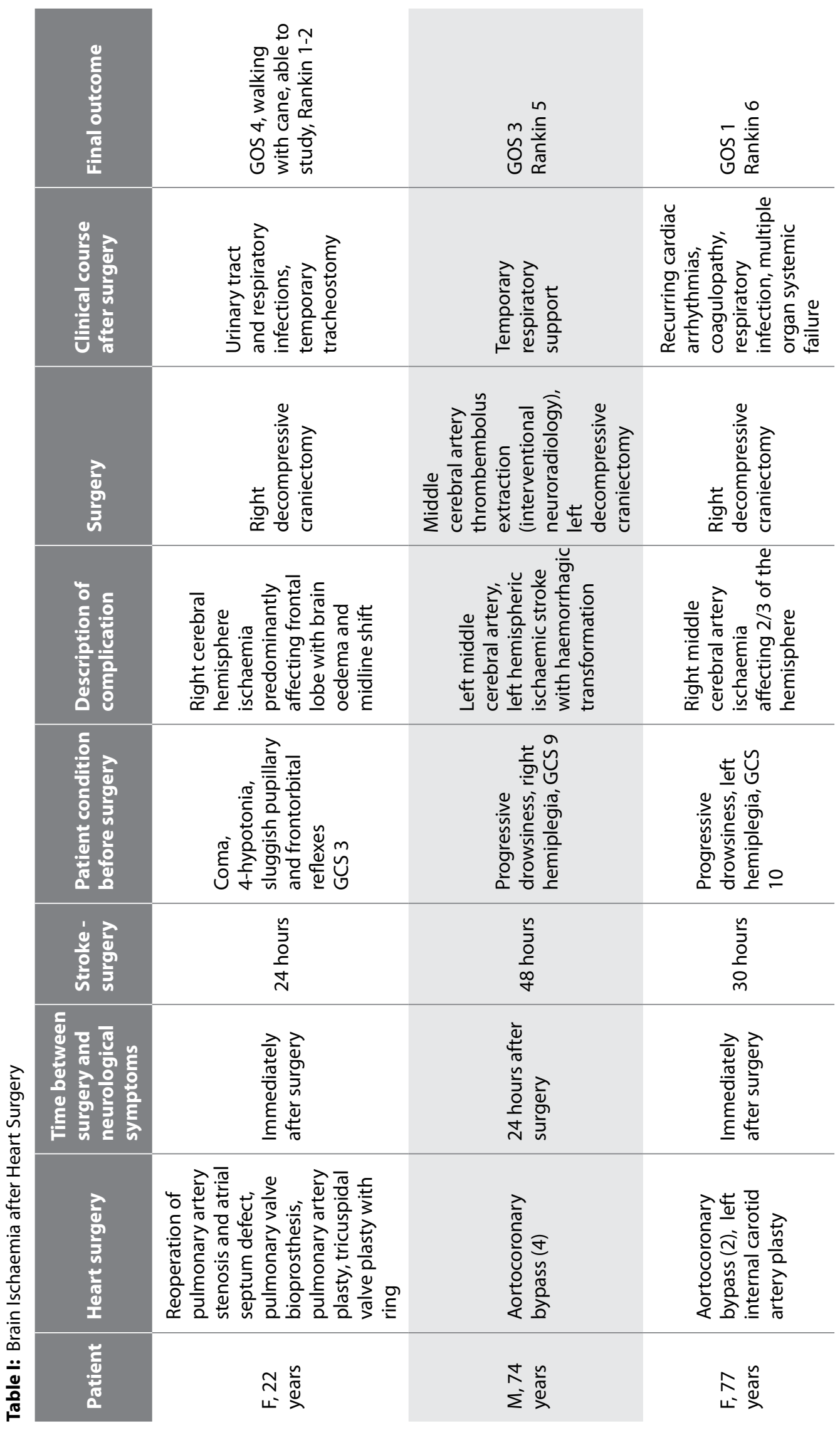




\begin{tabular}{|c|c|c|c|c|c|}
\hline 兽 & 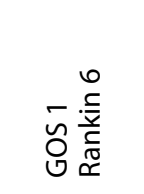 & 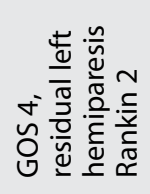 & 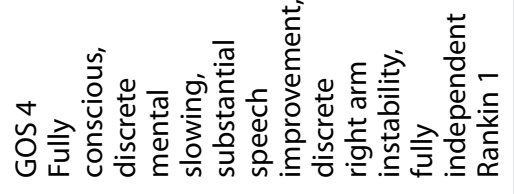 & 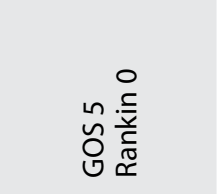 & 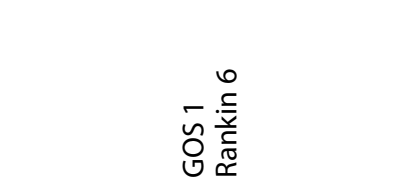 \\
\hline 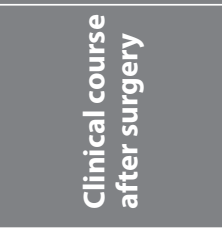 & 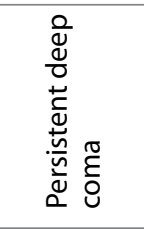 & 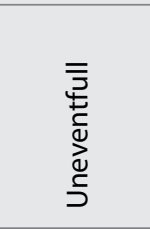 & 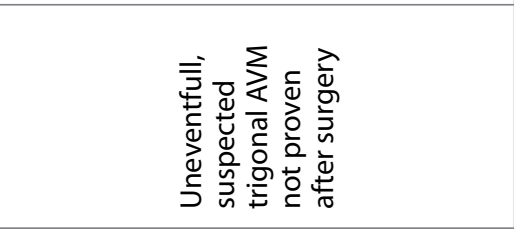 & 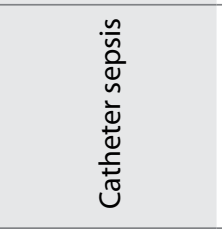 & 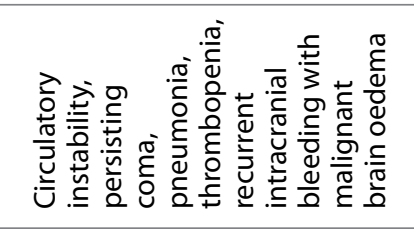 \\
\hline 胥 & 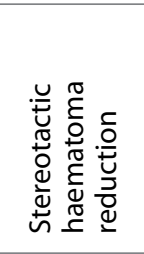 & 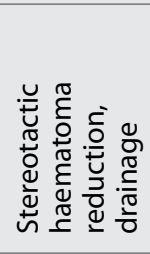 & 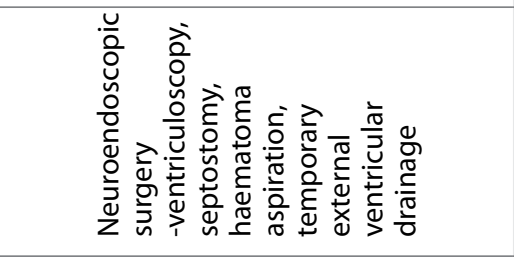 & 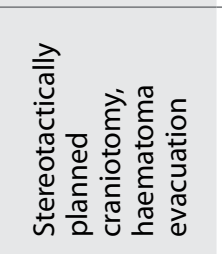 & 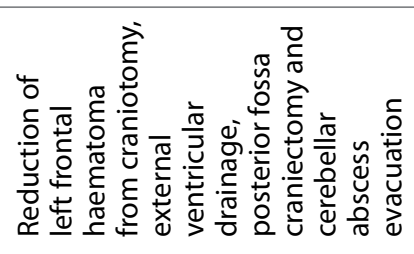 \\
\hline 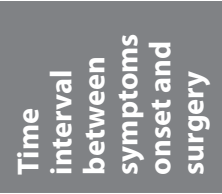 & 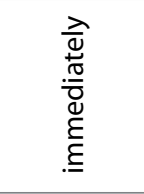 & 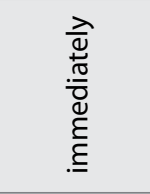 & 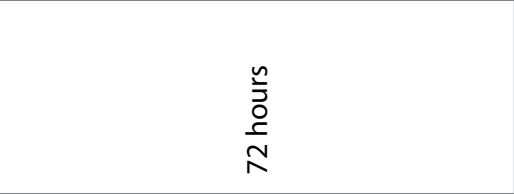 & 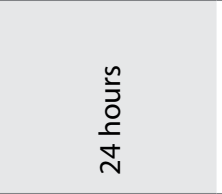 & 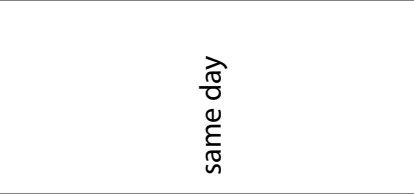 \\
\hline 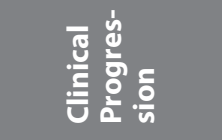 & ๑ & 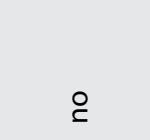 & 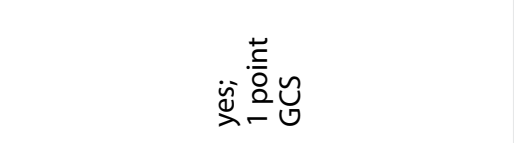 & 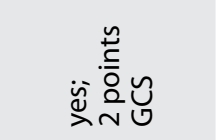 & 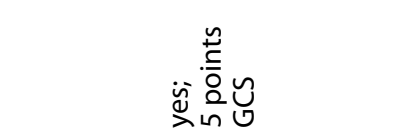 \\
\hline 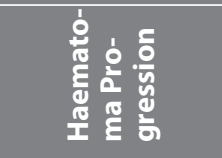 & 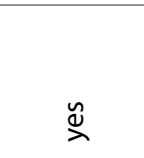 & $\stackrel{\circ}{\check{1}}$ & $\stackrel{\breve{\nu}}{\check{\lambda}}$ & 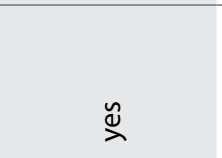 & 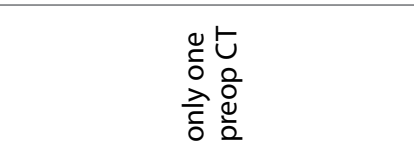 \\
\hline 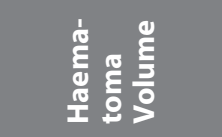 & $\begin{array}{l}\bar{\varepsilon} \\
\stackrel{o}{o}\end{array}$ & $\begin{array}{l}\bar{\varepsilon} \\
\stackrel{n}{n}\end{array}$ & 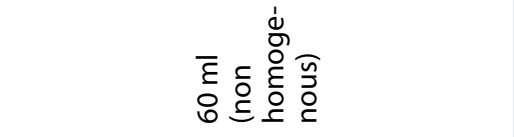 & $\begin{array}{l}\bar{\varepsilon} \\
\stackrel{n}{n}\end{array}$ & $\begin{array}{l}\bar{\varepsilon} \\
\stackrel{n}{n}\end{array}$ \\
\hline 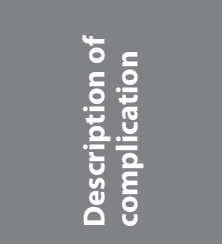 & 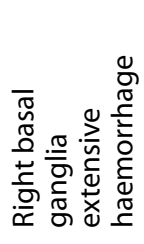 & 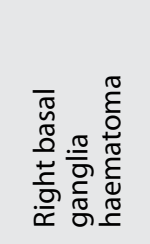 & 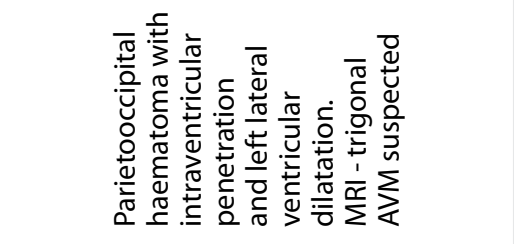 & 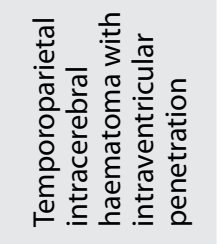 & 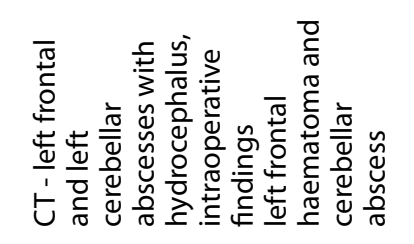 \\
\hline 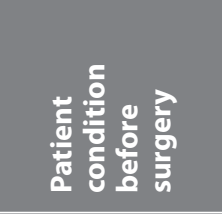 & 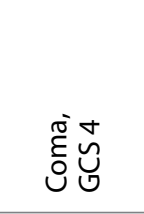 & 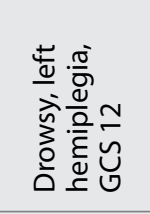 & 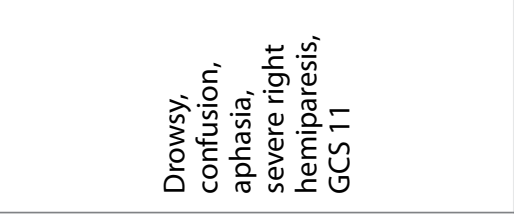 & 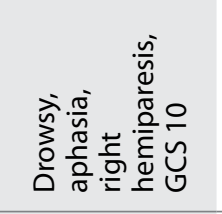 & 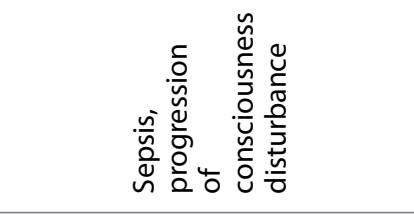 \\
\hline 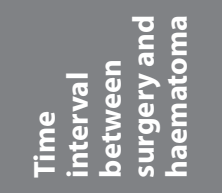 & 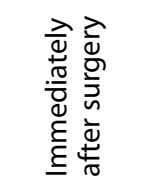 & 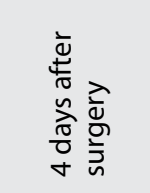 & 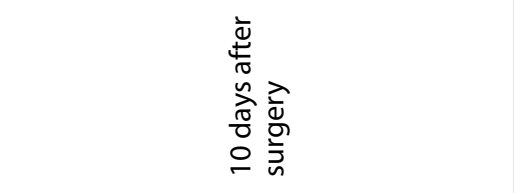 & 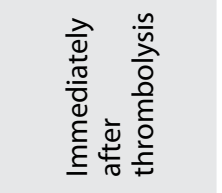 & 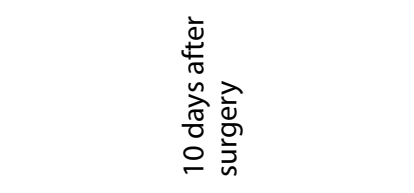 \\
\hline 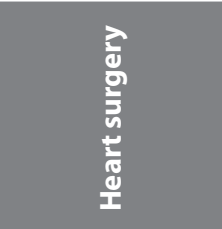 & 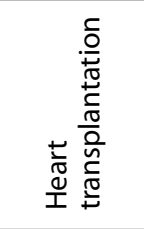 & 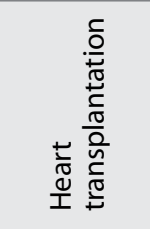 & 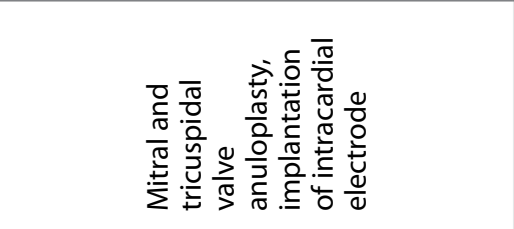 & 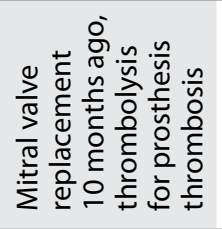 & 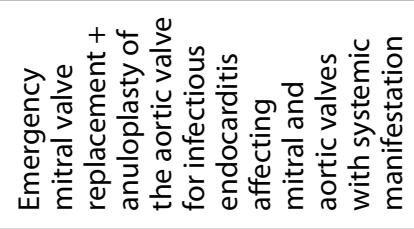 \\
\hline 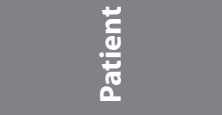 & 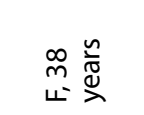 & 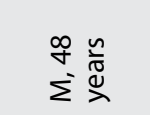 & 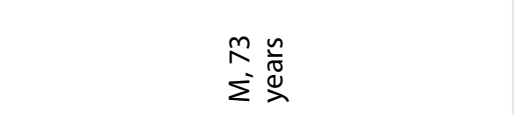 & 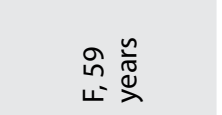 & 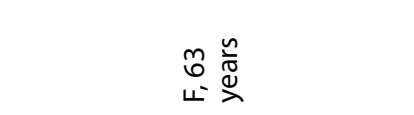 \\
\hline
\end{tabular}


Table III: General Principles of Antiaggregation / Anticoagulation Treatment after Heart Surgery

\begin{tabular}{|c|c|c|c|}
\hline Type of surgery & Day of surgery & $\begin{array}{l}\text { First day of surgery } \\
\text { (without bleeding problems) }\end{array}$ & Further course \\
\hline $\begin{array}{l}\text { Ischaemic heart } \\
\text { disease - bypass } \\
\text { surgery }\end{array}$ & $\begin{array}{l}\text { Coagulopathy correction } \\
\text { (clotting time, aPTT, platelets), } \\
\text { bedside thromboelastography } \\
\text { in bleeding problems }\end{array}$ & $\begin{array}{l}\text { Acetylosalicylic acid } 100 \mathrm{mg} / \\
\text { daily, unfractionated heparin } \\
5000-10000 \text { IU daily continual } \\
\text { infusions, bedside monitoring } \\
\text { of aPTT or ACT }\end{array}$ & $\begin{array}{l}\text { Oral acetylosalicylic acid } 100 \\
\text { mg/day + low molecular weight } \\
\text { heparin (LMWH) in prophylactic } \\
\text { dose - max. } 4000 \text { - } 6000 \text { IU } \\
\text { (patients weight, anti Xa) until } \\
\text { patient fully mobile }\end{array}$ \\
\hline $\begin{array}{l}\text { Mechanical heart } \\
\text { valve prosthesis }\end{array}$ & $\begin{array}{l}\text { Coagulopathy correction } \\
\text { (clotting time, aPTT, platelets), } \\
\text { bedside thromboelastography } \\
\text { in bleeding problems }\end{array}$ & $\begin{array}{l}\text { Unfractionated heparin } 5000 \\
-20000 \text { IU daily, continuous } \\
\text { infusions via central venous } \\
\text { catheter; bedside monitoring of } \\
\text { aPTT or ACT }\end{array}$ & $\begin{array}{l}\text { Warfarin, target INR } 2.5-3.0 \text {. } \\
\text { LMWH ( } 8000-20000 \text { IU anti } \\
\text { Xa until the effect of warfarin } \\
\text { therapy) }\end{array}$ \\
\hline $\begin{array}{l}\text { Biological heart valve } \\
\text { prosthesis (patient }< \\
70 \text { years) }\end{array}$ & $\begin{array}{l}\text { Coagulopathy correction } \\
\text { (clotting time, aPTT, platelets), } \\
\text { bedside thromboelastography } \\
\text { in bleeding problems }\end{array}$ & $\begin{array}{l}\text { Unfractionated heparin } 5000 \\
-20000 \text { IU daily continuous } \\
\text { infusions via central venous } \\
\text { catheter; bedside monitoring of } \\
\text { aPTT or ACT }\end{array}$ & $\begin{array}{l}\text { Warfarin, target INR } 2.5-3.0 \text {. } \\
\text { LMWH ( } 8000 \text { - } 20000 \text { IU anti } \\
\text { Xa until the effect of warfarin } \\
\text { therapy); after three months } \\
\text { of warfarin antiaggregation } \\
\text { (usually ASA } 200 \mathrm{mg} \text { ) lifetime }\end{array}$ \\
\hline $\begin{array}{l}\text { Biological heart valve } \\
\text { prosthesis (patient }> \\
70 \text { years) }\end{array}$ & $\begin{array}{l}\text { Coagulopathy correction } \\
\text { (clotting time, aPTT, platelets), } \\
\text { bedside thromboelastography } \\
\text { in bleeding problems }\end{array}$ & $\begin{array}{l}\text { Unfractionated heparin } 5000 \\
\text { - } 20000 \text { IU daily continuous } \\
\text { infusions via central venous } \\
\text { catheter; bedside monitoring } \\
\text { of aPTT or ACT; oral } \\
\text { antiaggregation - ASA } 200 \text { mg } \\
\text { daily. }\end{array}$ & $\begin{array}{l}\text { LMWH } 6000 \text { - } 10000 \text { IU anti } \\
\text { Xa until patient fully mobile; } \\
\text { antiaggregation life time } \\
\text { treatment (mainly ASA 200mg) }\end{array}$ \\
\hline Heart transplantation & $\begin{array}{l}\text { Coagulopathy correction } \\
\text { (clotting time, aPTT, platelets), } \\
\text { bedside thromboelastography } \\
\text { in bleeding problems }\end{array}$ & $\begin{array}{l}\text { Unfractionated heparin } 5000 \\
-20000 \text { IU daily continuous } \\
\text { infusions via central venous } \\
\text { catheter; bedside monitoring of } \\
\text { aPTT or ACT }\end{array}$ & $\begin{array}{l}\text { LMWH } 6000 \text { - } 8000 \text { IU until } \\
\text { fully mobile. Antiaggregation } \\
\text { therapy - several weeks } \\
\text { after surgery - reduction } \\
\text { of corticosteroids - cave } \\
\text { gastrointestinal bleeding }\end{array}$ \\
\hline
\end{tabular}

hours until stabilization of haemocoagulation. Haematoma progression and clinical worsening of the patient occurred during this time.

In the remaining 3 patients, there was no need for specific measures except for the temporary interruption of heparin treatment, which was restarted after postoperative CT. In patients with brain ischaemia, the ongoing heparin medication was not interrupted and antiaggregation therapy was initiated on an individual basis.

The surgical approach was individually tailored for each patient with intracerebral haematoma. Stereotactic haematoma aspiration was considered as a primary treatment and was sufficient in 2 patients. In 1 patient stereotactic aspiration of temporoparietal haematoma had to be abandoned due to the hard consistency of the clotted haematoma; the trephination was widened to a small temporal osteoclastic craniotomy permitting haematoma removal. In 1 patient with parietooccipital haematoma penetrating intraventricularly causing blockage of the left lateral ventricle, neuroendoscopic surgery (haematoma aspiration, septostomy, and temporary external ventricular drainage) was performed. In 1 patient multiple abscesses caused by infectious endocarditis affecting the mitral and aortic valves with systemic manifestation were suspected (frontal and cerebellar causing obstructive hydrocephalus). However, clotted haematoma was the surprising finding during the puncture of the suspected frontal abscess. Craniotomy evacuation of frontal haematoma, cerebellar abscess evacuation, and external ventricular drainage was performed. The final outcome was evaluated using Glasgow Outcome Scale (GOS) and Rankin scale.

\section{RESULTS}

\section{Cerebral Ischaemia after Heart Surgery}

The results of decompressive craniectomy for expansive middle cerebral artery infarction were severe disability (GOS 3 , Rankin 5) in one patient and death in one patient (recurring 
heart arrhythmias, coagulopathy, respiratory infection, and multiple organ failure). In a 22-year-old female with expansive right hemispheric ischemic stroke with clinical manifestation immediately after heart surgery, the final outcome was moderate disability (GOS 4, Rankin 1). Although with moderate to severe hemiparesis, she was able to continue her university studies.

\section{Intracranial Haematoma after Heart Surgery}

In the group of patients with intracerebral haematoma, the 2 patients operated on while in a comatose status (basal ganglionic haematoma immediately after heart transplantation and frontal haematoma with cerebellar abscess after emergency surgery for infectious endocarditis with systemic manifestation) died. 2 patients regained functional independence with final outcome of GOS 4 (Rankin 1 and 2). The remaining patient was discharged without neurological deficit (temporoparietal haematoma after endovascular thrombolysis for valvular prosthesis thrombosis).

\section{DISCUSSION}

\section{Cerebral Ischaemia after Heart Surgery}

Neurological complications are the second most significant cause of death after cardiac surgery (low cardiac output syndrome being the first). Hogue et al. examined the data from the Society of Thoracic Surgery/National Cardiac Surgery Database from 1996 and 1997 (416,347 patients) to determine the frequency of a new neurological event (stroke, TIA, or coma) after heart surgery. The incidence of such events was higher for females (3.8\%) than males $(2.4 \%)$, as was the mortality rate from these complications (females $32 \%$; males $28 \%$ ), even when adjusted for other risk factors (e.g., age, hypertension, and diabetes). The authors did not discuss the nature of the perioperative stroke (ischaemic or haemorrhagic) and did not mention the need for neurosurgical treatment (14).

Although rare (1.47\%), ischaemic stroke is a serious cause of morbidity and mortality after cardiac surgery (18). The causes of acute cardioembolic stroke after open heart surgery were evaluated by Maruyama et al. in a group of patients operated on early after cardioembolic stroke. From their group of 14 patients, 5 had vegetations in infective endocarditis (including prosthetic valve endocarditis) as embolic sources, 8 had intracardiac thrombi, and 1 had atrial myxoma. In 4 patients, the infarction was caused by large vessel occlusion, and in the remaining 10 patients there were cortical branch or perforating vessel occlusions (20).

Apart from cardioembolic stroke, infectious endocarditis may be a cause of intracerebral haematoma, with 1 case treated in our group. Infectious endocarditis may also be complicated by infectious aneurysms affecting the intracranial vessels (27). Cardiac myxoma association (even after complete tumor removal) with ischaemic strokes is described, but was not found in our group $(16,32)$.
The outcome of 2 patients over 60 years of age after decompressive craniectomy for middle cerebral artery ischaemia was unsatisfactory. This is confirmed by a retrospective analysis of studies on decompressive craniectomy for malignant middle cerebral artery infarction showing that mortality rates and functional outcomes were significantly worse in patients over 60 (3). Our attitude to surgery in these patients was determined by the in-hospital postsurgical origin onset of the stroke and the surprisingly good biological status of the male patient.

The outcome was satisfactory in the young female despite medical complications, grave neurological status, and extensive brain infarction.

Although the interval between the onset of neurological symptoms and decompressive craniectomy was less than 48 hours in all cases, earlier indications for decompressive craniectomy should be considered in patients with clinical symptoms and radiological findings suggesting extensive brain infarction after heart surgery. Although there were no cases of cerebellar ischaemia after heart surgery requiring surgical decompression in our group, surgical decompression would be undoubtedly indicated in patients after heart surgery with cerebellar ischaemia causing brainstem compression and obstructive hydrocephalus.

\section{Intracranial Haematoma after Heart Surgery}

In the large retrospective analysis of studies of intracranial haemorrhages after open heart surgeries performed by Yuan and Guo intracerebral haemorrhage was the most frequent $(41.21 \%)$, followed by subdural $(22.53 \%)$ and epidural haematomas (12.64\%). In patients with intracerebral haematomas, the frontal region was the most frequently affected (23.34\%) and the incidence of parietal, occipital, and temporoparietal haematomas was equal (12.99\%). No infratentorial haematomas were identified. Surgical evacuation was performed in $37.36 \%$ of patients, $14.84 \%$ of patients died untreated, $16.48 \%$ were treated conservatively, and in the remaining patients the treatment method was unknown. The overall treatment prognosis was poor: $56.59 \%$ of the patients died (34).

Epidural haematoma after heart surgery is a rare but serious complication $(2,15)$. The explanation is difficult but the cause may be unrecognised and unreported mild head injury before surgery exacerbated during heparin therapy.

Subdural haematoma after cardiac surgery can be attributed to several factors with the first being heparin administration with injury to the bridging veins. Especially in children, even head movements (intraoperative head turning) may elicit subdural bleeding $(19,34)$. Subdural bleeding may be also caused by changes in brain tissue volume, caused by fluid depletion leading to brain shrinkage and the possibility of bleeding into the widened subdural space, potentiated by anticoagulation treatment $(17,19,26)$. Subdural haematomas after heart surgery were also reported in adult patients (Kasahara et al. reported 2 cases) (17). 
Excessive loss of cerebrospinal fluid through lumbar drainage after thoracoabdominal aortic aneurysm surgery may cause brain tissue shrinkage, potentially resulting in subdural haematoma caused by stretching and tearing of the bridging veins. The incidence is $3.5 \%$ of patients after thoracoabdominal aortic aneurysm repair and the mortality is high at a rate of $50 \%$ (8). No patient with subdural haematoma after heart or aortic surgery was found in our group. One factor may be the use of endovascular stent grafts, which reduce the need for open thoracolumbar aneurysm surgery requiring lumbar drainage for individual patients/year.

The clinical picture and time course of intracerebral haematoma after heart surgery varies. Some patients fail to awaken from anaesthesia; others present with deteriorating levels of consciousness, pupillary abnormalities, hemiparesis, speech problems, and focal seizures occurring within hours to days after surgery $(15,34)$, although some symptoms may manifest as non-neurological symptoms, e.g ventricular dysrhythmia, low cardiac output syndrome, and lung oedema $(15,19)$.

Yuan and Guo tried to identify the possible risk factors responsible for intracerebral bleeding after heart surgery (34). In contrast to another study (14), males were more frequently affected. Preexisting neurological problems (seizure, history of head trauma, previous intracerebral haematoma, cerebral malformations) were found in a small percentage of cases. Intracerebral haematomas after heart surgery affect infants more frequently than adult patients (soft, less myelinated infant brain, small left atrium in congenital heart disease with pulmonary hypertension, and subsequent poor drainage of the vena cava) (18).

Other factors responsible for intracranial bleeding after heart surgery are hypocoagulation (e.g. heparin administration), hyperosmotic perfusion with brain shrinkage, hyperglycemia, and lifelong anticoagulation therapy in patients with mechanical heart valves and prosthetic endocarditis. The incidence of intracerebral haemorrhages in patients requiring extracorporeal membrane oxygenators or ventricular assist devices is $37 \%$ and $13-14 \%$ respectively $(10,13)$.

Surgeries for rheumatoid valve diseases and prosthetic valve endocarditis were the most likely to be complicated by intracranial bleeding. Aortocoronary bypass surgeries were complicated by intracranial bleeding only exceptionally $(1,14)$. In our group, intracerebral haematoma requiring neurosurgical treatment was found in 2 patients after heart transplantation, in 2 cases after heart valve surgery, and in 1 local thrombolysis.

The general prognostic factors in patients with intracerebral haematoma are haematoma location and volume, haematoma growth, level of consciousness and neurological findings, dynamics of clinical status (worse prognosis in deteriorating patients), age, and general clinical condition (24). Oral anticoagulation therapy and possibly antiplatelet therapy appear to be associated with worse outcome (30).
This is of particular importance in patients after heart surgery.

According to the study by Broderick, intracerebral haematoma volume $>60 \mathrm{~cm}^{3}$ and a GCS 8 or less predicted a 30-day mortality rate of $91 \%$. Haematoma volume $<30 \mathrm{~cm}^{3}$ and GCS 9 or more predicted a 30-day mortality of 19\% (4).

Haematoma volume was equal to or greater than $60 \mathrm{~cm}^{3}$ in 3 patients. The outcome was lethal in 1 comatose patient with basal ganglionic haematoma after heart transplantation. In the remaining 2 patients undergoing surgery for large lobar haematomas (temporoparietal and parietooccipital with haemocephalus) the final outcomes were GOS 5 and 4.

The final outcome was GOS 4 in the patient with a $35 \mathrm{ml}$ haematoma affecting the basal ganglia, with improvement of severe hemiparesis, permitting the patient to walk with a cane. In 1 patient with suspected multiple brain abscesses, the volume of the frontal haematoma was $15 \mathrm{ml}$.

Haematoma size progression also predicts increased mortality and poor outcome. An absolute increase of haematoma volume has a higher predictive value than relative increases (9). In our group it was possible to study haematoma dynamics in 4 patients. In 2 patients, the first CT was performed after complication onset and the second as a planning scan for stereotactic surgery. In another 2 patients, 3 CT scans were performed before surgery: the first diagnostic $\mathrm{CT}$, the second a follow up scan, and the third a planning scan for stereotactic surgery. Haematoma progression was noted in 3 patients, with a good outcome for 1 , satisfactory for 1 , and a lethal outcome for 1 patient.

Early neurological deterioration 48 hours after bleeding onset caused by either haematoma enlargement, hydrocephalus, or brain oedema is associated with a poor prognosis (23). Clinical deterioration after haematoma diagnosis was observed in 3 patients, with 1 lethal outcome, 1 with GOS 5, and 1 with GOS 4. The patient with lethal outcome deteriorated into a coma from an initial GCS 10.

Intracerebral haemorrhage is associated with high mortality in patients on anticoagulation treatment (52\% - 73\%) and the proportion of expanding haematoma at 72 hours is also higher in patients with anticoagulation (56\% versus $26 \%)(7,30,31,33)$. The evidence regarding the prognosis with antiplatelets after intracerebral haemorrhage is less convincing. There are studies reporting worse haematoma prognosis or greater haematoma enlargement associated with antiplatelets $(5,25)$, while other studies do not (11).

The treatment measures used to normalize haemocoagulation include vitamin K (very slow response time), fresh frozen plasma (fluid overload, slow response), and prothrombin complex concentrates with narrow therapeutic windows (potentially inducing thrombosis) (21). There is a risk of creating a prothrombotic state during acute anticoagulation reversal, but the risk of haematoma progression outweighs this risk (11). The recombinant activated factor promotes haemostasis in patients with normal coagulation by acting 
locally without activating systemic haemostasis (22) and may reduce the progression of haematoma early after stroke (6).

The indication for surgery in patients with intracerebral haematomas depends on the haematoma location. Haematoma evacuation should be performed in patients with cerebellar haemorrhages $>3 \mathrm{~cm}$ in diameter who are deteriorating or have brainstem compression and/or hydrocephalus due to ventricular obstruction (24). There was no intracerebellar haematoma in our group of patients. Only an exceptional case of cerebellar haematoma after coronary artery bypass was published (1).

For patients with supratentorial intracerebral haemorrhage, current guidelines and the results of the STICH trial suggest haematoma evacuation with standard craniotomy in patients with lobar clots $>30 \mathrm{~cm}^{3}$, within $1 \mathrm{~cm}$ of the surface $(5,24)$.

The lethal outcome in the case of a young female patient, comatose immediately after heart transplantation, was caused by the extent of basal ganglionic haematoma. The patient was operated on early in the time period (before the STICH trial), and the active attitude was determined by the patient's age and social aspects. The decision to perform stereotactic haematoma reduction in the second basal ganglionic haematoma was supported by haematoma subcortical perforation approximately $1.5 \mathrm{~cm}$ from the cortical surface. All the remaining haematomas affected subcortical structures extending less than $1 \mathrm{~cm}$ from the cortical surface, and in 2 of them the haematoma volume exceeded $60 \mathrm{~cm}^{3}$. Even though the expected prognosis in the limited group of patients operated on for intracerebral haematoma complicating the postoperative course after heart surgery is worse than in the non-cardiac population, a good outcome or moderate disability was achieved in 3 of 5 critically ill patients with the use of minimally invasive surgery techniques (stereotactic haematoma puncture or without drainage and fibrinolysis, neuroendoscopic surgery and microsurgical haematoma evacuation using navigated craniotomy in 4 of 5 patients). This group of patients is limited (very rare incidence of neurosurgical complications) and very heterogenous in terms of patients characteristics, type of cardiosurgical procedures, nature of neurological complications and neurosurgical measures taken but the results may support the use of minimally invasive techniques in selected patients with intracerebral haematoma complicating postoperative course after heart surgery. Literature data also support the use of stereotactic haematoma puncture with fibrinolysis (29) or neuroendoscopic treatment in patients with coagulopathies $(2,28)$.

\section{CONCLUSIONS}

Critical neurological events requiring neurosurgical treatment can occur after cardiac surgery and must be recognized early and properly treated with attention paid to medical comorbidities and particular risks after heart surgery unusual in the general neurosurgical population. Surgical indications should be carefully considered in terms of risks versus benefits. Presurgical plans should include proper surgical timing enabling adequate time for presurgical preparation, particularly anticoagulation therapy reversal, treatment of circulatory instability, and the need for vital function support. Minimally invasive neurosurgery techniques may be beneficial for this particular group of high-risk patients and should be considered as a treatment option.

\section{REFERENCES}

1. Anderson DE, Biller J, Schreiber RR: Spontaneous cerebellar hemorrhage after coronary artery bypass surgery. Eur Neurol 24: 145-148, 1985

2. Anegawa S, Hayashi T, Furukawa $Y$, Nagashima T, Kumate M: Spontaneous epidural haematoma after open heart surgery: Case report. No Shinkei Geka 27: 23-26, 1999

3. Arac V, Blanchard V, Lee M, Steinberg GK: Assessment of outcome following decompressive craniectomy for malignant middle cerebral artery infarction in patients older than 60 years of age. Neurosurg Focus 26(6): E3, 2009

4. Broderick JP, Brott TG, Duldner JE, Tomsick T, Huster G: Volume of intracerebral hemorrhage. A powerful and easy to use predictor of 30 days mortality. Stroke 24: 987-993, 1993

5. Broderick J, Connolly S, Feldmann E, Hanley D, Kase C, Krieger F, Mayberg M, Morgenstern L, Ogilvy CS, Vespa P, Zuccarello M: Guidelines for the management of spontaneous intracerebral hemorrhage in adults: 2007 update: A guideline from the American Heart Association: American Stroke Association Stroke Council, High Blood Pressure Research Council and the Quality of Care and Outcomes in Research Interdisciplinary Working Group. Stroke 38: 2001-2023, 2007

6. Conti S, La Torre D, Gambelunghe G, Ciorba E, lorio A: Successful treatment of a spontaneous intracerebral hemorrhage with $\mathrm{rf} \mathrm{VII} \mathrm{in} \mathrm{patient} \mathrm{with} \mathrm{mechanical} \mathrm{prosthetic}$ heart valves. Clin Lab Haematol 27: 283-285, 2005

7. Cucchiara B, Messe S, Sansing L, Kasner S, Lyden P: CHANT Investigators. Hematoma growth in oral anticoagulant related intracerebral hemorrhage. Stroke 39: 2993-2996, 2008

8. Dardik A, Perler BA, Rosenborough GS, Williams GM: Subdural haematoma after thoracoabdominal aortic aneurysm repair: An underreported complication of spinal fluid drainage. J Vasc Surgery 36: 47-50, 2002

9. Dowlatshahi $D$, Demchuk AM, Flaherty ML, Ali M, Lyden PL, Smith EE: VISTA Collaboration. Defining haematoma expansion in intracerebral hemorrhage: Relationship with patient outcomes. Neurology 76(14): 1238-1244, 2011

10. Factora FN, Bustamante S, Spiotta A, Avitsian R: Intracranial hemorrhage surgery on patients on mechanical circulatory support: A case series. J Neurosurg Anesthesiol 23: 30-34, 2011

11. Foerch C, Sitzer $M$, Steinmetz $H$, Neumann-Haefelin T: Pretreatment with antiplatelet agents is not independently associated with unfavourable outcome in intracerebral hemorrhage. Stroke 37: 2165-2167, 2006

12. Genewein U, Haeberli A, Straub PW, Beer JH: Rebound after cessation of oral anticoagulant therapy: The biochemical evidence. Br J Haematol 92: 479-485, 1996 
13. Hervey- Jumper SL, Annich GM, Yancon AR, Ganton HJ, Muraszko KM, Maher CO: Neurological complications of extracorporeal membrane oxygenation in children. J Neurosurg Pediatr 7: 338-344, 2011

14. Hogue CW Jr, Barzilai B, Pieper KS, Coombs LP, DeLong ER, Kouchoukos NT, Davila-Román VG: Sex difference in neurological outcomes and mortality after cardiac surgery: a society of thoracic surgery national database report. Circulation 103: 2133-2137, 2001

15. Humphreys RP, Hoffman HJ, Mustard WT, Trusler GA: Cerebral hemorrhage following heart surgery. J Neurosurg 43: 671675,1975

16. Jean WC, Walski - Easton SM, Nussbaum ES: Multiple intracranial aneurysma as delayed complications of an atrial myxoma: Case report. Neurosurgery 49: 200-202, 2001

17. Kasahara S, Sakai A, Isomatsa Y, Akishima S, Nie N, Oosawa M: Subdural haematoma complicated after open heart surgery: A report of two cases with successful treatment. Kyobu Geka 47: 732-735, 1994

18. Korn Lubetzki I, Oren A, Tauber R, Bitran D, Steiner -Birmans $B$ : No symptomatic intracerebral haemorrhage after cardiac surgery: 14 years retrospective study. Eur Neurol 64: 351-354, 2010

19. Krous HF, Tenckhoff L, Gould NS, Stamm SJ: Subdural haematoma following open-heart operations. Ann Thorac Surg 19: 269-276, 1975

20. Maruyama M, Kuriyama Y, Sawada T, Yamaguchi T, Fujita T, Omae T: Brain damage after open heart surgery in patients with acute cardioembolic stroke. Stroke 20: 1305-1310, 1989

21. Masotti L, Di Napoli M, Godoy DA, Rafanelli D, Liumbruno G, Koumpouros N, Landini G, Pampana A, Cappelli R, Poli $D$, Prisco D: The practical management of intracerebral haemorrhage associated with oral anticoagulant therapy. Int J Stroke 6: 228-240, 2011

22. Mayer SA, Rincon F: Ultra-early hemostatic therapy for acute intracerebral haemorhage Semin Hematol 43 Suppl (1):S70-S76, 2006

23. Mayer SA, Sacco RL, Shi T, Mohr JP: Neurologic deterioration in non comatose patients with supratentorial intracerebral hemorrhage. Neurology 44: 1379-1384, 1994
24. Morgenstern LB, Hemphill JC 3rd, Anderson C, Becker K, Broderick JP, Connoly ES Jr, Greenberg SM, Huang JN, Mac Donald RL, Mess SR, Mitchell PH, Selim M, Tamaro RJ: American Heart Association Stroke Council and Council on Cardiovascular Nursing. Guidelines for the management of spontaneous intracerebral hemorrhage: A guideline for healthcare professionals from the American Heart Association /American Stroke Association. Stroke 41: 2108-2129, 2010

25. Naidech AM, Jovanovic B, Liebling S, Garg RK, Bassi SL, Bendok BR, Bernstein RA, Alberts MJ, Batjer HH: Reduced platelet activity is associated with early clot growth and worse 3 - months outcome after intracerebral hemorrhage. Stroke 40: 2398-2401, 2009

26. Oka K, Kamota T, Satou M, Murakami M, Kobayashi T, Shirasawa B, Mikamo A, Hamano K: Subdural haematoma following cardiac surgery Kyobu Geka 61: 868-872, 2008

27. Okabe S, Ottomo M, Momokawa T, Takahashi K: Intracranial bacterial aneurysms - report of two cases with special reference to operative indications. No Shinkei Geka 15: 983988,1987

28. Orakcioglu B, Uozumi Y, Unterberg A: Endoscopic intrahematoma evacuation of intracerebral hematomas - a suitable technique for patients with coagulopathies. Acta Neurochir 112(Suppl): S3-S8, 2011

29. Rohde V, Uzma N, Rohde I, St Clair I, Samadani U: Fibrinolytic therapy versus craniotomy for anticoagulant - associated intracerebral hemorrhage. Clin Neurol Neurosurg 111: 518522, 2009

30. Saloheino P, Ahonen M, Juvela S, Pyhtinen J, Savolainen ER, Hillborn M: Regular aspirin - use preceding the onset of primary intracerebral hemorrhage is an independent predictor for death. Stroke 37: 129-133, 2006

31. Steiner T, Rosand J, Diringer M: Intracerebral haemorrhage associated with oral anticoagulant therapy: Current practises and unresolved questions. Stroke 37: 256-262, 2006

32. Tamulevičiute $E$, Taeshineetanakul $P$, Terbrugge $K$, Krings $T$ : Myxomatous aneurysms: A case report and literature review. Interv Neuroradiol 17: 188-194, 2011

33. Wijdics EF, Schievink WI, Brown RD, Mullany CJ: The dilemma of discontinuation of anticoagulation therapy for patients with intracranial hemorrhage and mechanical heart valves. Neurosurgery 42: 769-773, 1998

34. Yuan SM, Guo JQ: Subsequent intracranial heamorrhage following open heart surgery. Ann Coll Surg Hong Kong 5: 66-73, 2001 